\title{
Konsep Pengembangan Sumber Daya Manusia Berbasis Kompetensi, Bakat dan Ketahanan dalam Organisasi
}

\author{
Yostan A. Labola \\ SMP Negeri Satu Atap Fatukoto, Timor Tengah Selatan \\ yostan87@gmail.com
}

\begin{abstract}
Many companies have poor performance because they don't have human resources relevated with their needs. Some of those organizations will not survive for long term in business competition. In this case Human Resource Development (HR) becomes a fundamental parameter for the success and achievement of organizational goals in order to exist. Based on literature review, the concept of developing an HR organization needs to pay attention on aspects of competence, talent, and resilience of employees. The competency aspect is the potential longterm value and potential source of the company's competitive advantage. While the talent aspect becomes a critical point for the company for the positions needed, and with the toughness aspect, employees are able to face competition and overcome difficulties to become opportunities for greater achievement. Thus, the vision, mission and expectations of the organization can lead to success.
\end{abstract}

Keywords : Competence, Human Resource Development, Resilience, Talent

\section{PENDAHULUAN}

Era ini ditandai dengan persaingan global yang sangat memikat. Kompetisi yang terjadi, menjadi bahan telaah demi pengembangan sumber daya suatu perusahaan/institusi/organisasi. Sumber Daya Manusia (SDM) merupakan asset penting organisasi manapun untuk mencapai keunggulan kompetitif di era globalisasi. Karena itu, Pengembangan Sumber Daya Manusia (PSDM) menjadi parameter penting bagi organisasi untuk untuk mencapai tujuan dan sasaran agar tetap eksis di kancah Nasional maupun Internasional. PSDM adalah fungsi organisasi yang berfokus pada rekrutmen, pengelolaan, dan navigasi bagi karyawan dalam bekerja pada suatu organisasi yang diwujudkan melalui sinergi untuk memperkuat mutualitas menuju tujuan bersama. Susan (2012) menyampaikan bahwa PSDM merupakan pendekatan strategis dan menyeluruh untuk mengelola orang, budaya tempat kerja, dan lingkungan untuk secara efektif berkontribusi dan produktif ke tujuan dan sasaran organisasi.

Beberapa tahun terakhir, banyak perusahaan yang baik berkinerja buruk akibat SDM yang tidak efektif dan efisien (Townsend and Wilkinson, 2010; Okoye dan Ezejiofor, 2013). Sebagian besar organisasi mengabaikan pengembangan SDM sebagai asset utama. Okoye dan Ezejiofor (2013) mengatakan bahwa bisnis dalam suatu organisasi dipenuhi ketidakpastian pemahaman terhadap kontribusi karyawan dalam peningkatan produktivitas organisasi dan profitabilitas. Hal inilah yang menyebabkan banyak tenaga kerja kurang terampil, organisasi tidak kompetitif, tingkat 
tinggi kinerja yang buruk, dan produktivitas yang rendah. Berbagai upaya dilakukan oleh organisasi dengan memberi penekanan pada karyawannya terkait peningkatan kinerja demi output dan outcome menguntungkan sebagai efek jangka panjang (shodhganga.inflibnet.ac.in). Upaya manajemen SDM bertujuan meningkatkan karyawan menangani beragam jenis tugas demi memperkuat daya saing organisasi dan adaptasi terhadap lingkungan, kususnya turbulensi eksternal (Jumawan, 2015) sekaligus bermanfaat bagi karyawan demi peningkatan karir, peningkatan kompetensi, dan pengembangan bakat.

PSDM meningkatkan produktivitas dengan kualitas tinggi, pelanggan terpuaskan, dan memberi dampak menguntungkan bagi organisasi. Sejalan dengan apa yang disampaikan Pfeffer (1998) bahwa "the key to long-term success has been, and will continue to be, how organizations manage their employees, because creating meaningful work and otherwise keeping employees happy is central to fostering organizational effectiveness".

Seringkali organisasi mengalami kendala serius dalam mengelola karyawan bekerja secara optimal. Senada dengan Simon (1997) bahwa "the basic challenge for all organizations is "inducing their employees to work toward organizational goals”. Padahal untuk mencapai kesuksesan jangka panjang dan berlanjut, organisasi memerlukan PSDM yang menciptakan kerja berarti (sesuai bakat dan kompetensi karyawan). Selain bakat dan kompetensi, organisasi perlu memperhatikan aspek ketahanan atau ketangguhan karyawan dalam bekerja agar suatu organisasi tetap eksis dalam jangka panjang.

Banyak organisasi bisnis kompetitif yang muncul belakangan ini. Akan tetapi, keberadaan organisasi-organisasi bisnis tersebut tidak bertahan lama. Hal ini karena, pengusaha tidak memperhatikan aspek ketahanan atau ketangguhan karyawan dalam perekrutan. Padahal selain bakat dan keterampilan suatu pekerjaan sangat membutuhkan ketahanan dalam bekerja. Uraian ini ingin mengulas pentingnya memperhatikan karyawan yang memiliki ketahanan atau ketangguhan dalam bekerja.

\section{METODE}

Artikel ini adalah studi literatur, yakni serangkaian kegiatan yang berkaitan dengan metode pengumpulan data melalui membaca dan merekam, serta mengelola bahan penelitian (Prabawati dkk., 2018). Studi literatur dilakukan dengan penelusuran pustaka buku, artikel, jurnal nasional dan internasional serta penggunaan kamus dan thesaurus. Pustaka yang digunakan disesuaikan dengan judul kajian tentang Konsep Pengembangan Sumber Daya Manusia (SDM) Berbasis Kompetensi, Bakat dan Ketahanan Dalam Organisasi.

\section{HASIL DAN PEMBAHASAN \\ Pengembangan Sumber Daya Manusia Dalam Organisasi}

Pengembangan organisasi bertujuan menjembatani perubahan dan pengembangan baik dari sisi internal maupun eksternal. Hal ini dikarenakan produktifitas tergantung pada efektifitas kerja karyawannya. Artinya, kualitas organisasi ditentukan oleh SDM yang ada dan pengembangan SDM ditentukan oleh perubahan-perubahan nyata yang mengarah pada pertumbuhan organisasi.

Konsep Pengembangan Sumber Daya Manusia (PSDM) dalam organisasi, hakikatnya merupakan suatu usaha demi peningkatan daya saing terhadap ancaman lingkungan eksternal dan upaya meningkatkan daya inovatif demi menciptkan peluang. PSDM dalam organisasi bersifat integral sebagai individu dan sistem serta organisasi sebagai wadah SDM secara terencana dan berkesinambungan untuk menigkatkan kompetensi pekerja melalui program pelatihan, pendidikan, dan pengembangan (Noe, 2008).

Secara umum PSDM bertujuan untuk: 1) membentuk individu dari aspekaspek ketrampilan, pengetahuan dan sikap; 
2) pengembangan karir; 3) mengatur dan membina manusia sebagai sub sistem organisasi melalui program-program perencana dan penilaian seperti perencanaan tenaga kerja, penilaian kinerja, analisis pekerjaan, dan klasifikasi pekerjaan; 4) mendapat SDM sesuai klasifikasi kebutuhan organisasi dan alat organisasi yang bertujuan untuk perbaikan dan peningkatan; 5) penyesuaian sistem dan kebijakan organisasi sebagai penangkal risiko dan faktor eksternal.

Konsep PSDM perlu menyentuh seluruh aspek kehidupan karyawan sebagai manusia seutuhnya (Hutagalung, 2008). Organisasi perlu memahami bahwa individu mempunyai keluarga dan kehidupan sosial sehingga tercipta kondisi timbal balik yang menguntungkan. Artinya untuk memiliki karyawan berdaya guna dalam sebuah organisasi maka aspek kemanusian fundamental dalam pengembangan karyawan.

PSDM diakui sebagai bagian esensial dari manajemen SDM organisasi. Tujuan dari manajemen SDM yakni tersedianya relasi lebih baik dalam organisasi melalui pengembangan, aplikasi, evaluasi kebijakan, prosedur dan program SDM untuk pengoptimalan kontribusi terhadap tujuan organisasi. Dalam PSDM harus memperhatikan empat kegiatan utama, seperti akuisisi, pengembangan, motivasi, dan pemeliharaan SDM. Disimpulkan bahwa, PSDM adalah fungsi organisasi yang memberi arahan bagi orang-orang dalam suatu organisasi terkait pengelolaan SDM dengan fokus pada kebijakan dan sistem.

PSDM biasanya bertanggung jawab untuk sejumlah kegiatan, termasuk perekrutan karyawan, pelatihan dan pengembangan, motivasi, penilaian kinerja, kompensasi, perekrutan, manajemen kinerja, pengembangan organisasi, keselamatan, kesejahteraan, manfaat, dan penghargaan. Selain beberapa hal di atas, konsep pengembangan SDM perlu memperhatikan bakat karyawan sehingga terjadi peningkatan performace individu yang bermuara pada tujuan organisasi. Lebih lanjut, apabila pengembangan SDM dalam organisasi memperhatikan aspek ketahanan, akan melahirkan karyawan yang tangguh dalam bekerja dan tidak mudah putus asa dalam pekerjaannya. Dengan demikian memberi dampak pada organisasi yang efektif dan tercapainya tujuan organisasi. Konsep Pengembangan SDM yang diusulkan ditunjukkan pada skema Gambar 1.

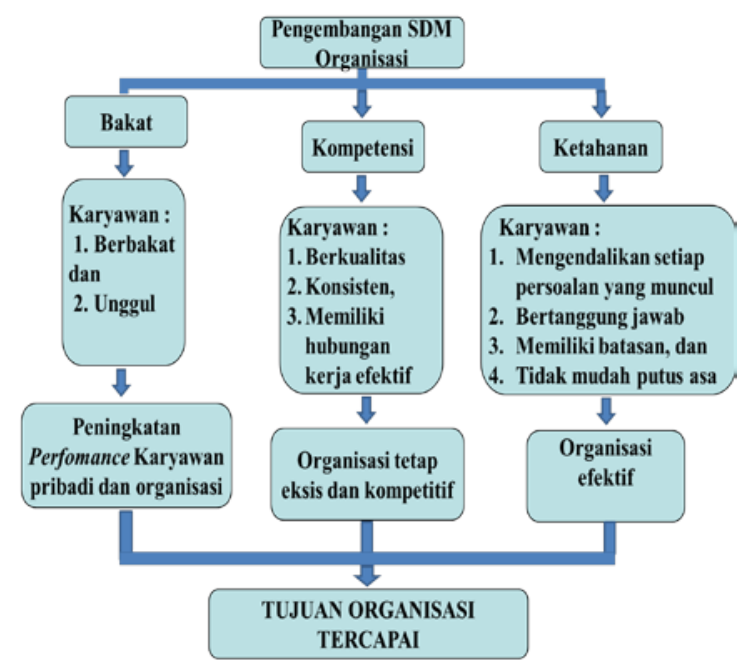

Gambar 1. Model Konsep Pengelolaan SDM Organisasi

\section{Pengembangan Sumber Daya Manusia Organisasi Berbasis Kompetensi}

Spencer dan Spencer

mendefinisikan kompetensi sebagai karakteristik mendasar seseorang yang secara kasual berkaitan dengan kinerja efektif atau superior dalam berbagai situasi dan pekerjaan. Secara umum, istilah kompetensi dimaknai sebagai kombinasi keterampilan, karakter personal, dan pengetahuan yang diamati, diukur dan dievaluasi melalui kinerja. Terdapat dua jenis kompetensi, yaitu :1) kompetensi manajerial, untuk pengelolaan karyawan dan membangun relasi sosial; 2) kompetensi teknis, berkaitan dengan kapasitas fungsional pekerjaan yang dilakukan.

Pengembangan SDM berbasis kompetensi mendukung integrasi perencanaan SDM dengan perencanaan bisnis organisasi. Untuk itu, organisasi dapat menilai kapasitas SDM berdasarkan kompetensi terhadap kemampuan yang dibutuhkan dalam mencapai visi, misi dan 
tujuan organisasi (Tripathi dan Agrawal, 2014). Sejalan dengan Kamidin (2010) yang menyatakan bahwa pengembangan SDM yang berprinsip pada visi dan misi organisasi meningkatkan kinerja organisasi.

Apabila PSDM memperhatikan kompetensi yang dimiliki oleh karyawan, maka tercipta daya saing dan eksistensi organisasi. PSDM dimulai dari rekrutmen, seleksi, identifikasi kompetensi aspek inisiatif, motivasi berprestasi, kemampuan bekerja dalam tim, pengumpulan informasi kompetensi terkait calon karyawan, penilaian terhadap calon karyawan melalui tes yang sesuai, hingga pengembangan berkelanjutan. Selanjutnya seluruh kegiatan, pendidikan, dan pelatihan perlu dilakukan sesuai dengan kompetensi yang dimiliki karyawan.

Secara umum ada beberapa hal yang perlu diperhatikan untuk mencapai pengembangan sumber daya manusia optimal (Jumawan, 2015) yaitu: 1) seleksi sumber daya manusia sesuai dengan kebutuhan; 2) merancang keselarasan antara kebutuhan organisasi dan kompetensi karyawan; 3) menyediakan sarana, prasarana dan teknologi yang sesuai; 4) Komitmen yang tinggi dari setiap elemen organisasi.

Draganidis dan Mentza (2006) menyampaikan bahwa tahapan lain yang sangat penting dalam pengembangan SDM berbasis kompetensi, yaitu: 1) Identifikasi kompetensi. Proses menemukan kompetensi yang diperlukan untuk kinerja sukses dan optimal; 2) Model kompetensi. Gambaran naratif kompetensi untuk target kategori pekerjaan, kelompok pekerjaan, divisi, departemen atau unit analisis lainnya; 3) Penilaian kompetensi. Proses membandingkan kompetensi individu pada model kompetensi; 4) Manajemen berbasis kompetensi. Penerapan serangkaian kompetensi untuk mengelola sumber daya manusia sehingga kinerja berkontribusi secara efisien dan efektif untuk tujuan organisasi; 5) Standar kompetensi. Identifikasi keterampilan dan pengetahuan pekerja yang dimiliki karyawan dan menentukan tingkat kinerja yang harus capai dalam segmen atau fungsi kerja tertentu; 6)
Profil kompetensi. Dokumen yang menggambarkan kumpulan kompetensi tertentu ke posisi/pekerjaan/ kelompok pekerjaan/komunitas fungsional.

PSDM berbasis kompetensi juga diharuskan memperhatikan tingkat manajemen yang ada, baik dari tingkat eksekutif, manajer, dan karyawan sehingga penerapan pengembangan SDM sesuai dengan kebutuhan tingkatan masing-masing. Untuk tingkat eksekutif kompetensi yang dibutuhkan meliputi aspek strategi berpikir dan perubahan-perubahan pada manajemen oleh pimpinan. Sementara tingkat manajer memerlukan kompetensi pada aspek perubahan implementasi, pemahaman interpersonal dan pemberdayaan. Sementara pada tingkat karyawan sangat diperlukan kompetensi seperti fleksibilitas, update informasi, motivasi dan kemampuan belajar, motivasi (berprestasi dan kerja di bawah tekanan waktu), kolaborasi, dan orientasi pelayaanan kepada pelanggan.

Alasan suatu perusahaan menerapkan PSDM berbasis kompetensi karena kompetensi merupakan sumber nilai potensial jangka panjang dan sumber potensial keunggulan kompetitif perusahaan. Misalnya, dengan kompetensi tinggi dalam PSDM, praktisi SDM mengambil hati manajemen puncak untuk melihat beberapa masalah penting terkait SDM, menyampaikan informasi dan visi masalah bisnis, bekerja dengan penuh ketelitian, dan bersama manajer berupaya mencari solusi serta menyelesaikan permasalahan karyawan (Wei dan Lau, 2005). Selain itu, Long dan Ismail (2011) menyampaikan bahwa praktisi SDM membantu mengembangkan karyawan yang eksplisit dan menghasilkan pengetahuan.

Individu dengan kompetensi kerja yang berkualitas akan bertanggung jawab dan menjadi "bunglon" dalam setiap perubahan lingkungan kerja. Sejalan dengan Raven dan Stephenson (2001) bahwa kompetensi mengarahkan seseorang untuk terus belajar dan beradaptasi. Aspek kompetensi erat hubungannya dengan PSDM, yakni konsistensi organisasi dalam 
pengembangan karyawan. Karena itu, setiap perusahaan perlu mendefinisikan dan merencanakan model tertentu dalam PSDM, seperti rekrutmen, analisis kesenjangan keterampilan, rencana pengembangan pekerjaan, upaya pelatihan, pembelajaran mandiri, manajemen pembelajaran, penilaian diri, dan motivasi (Kemp dkk., 2004).

Organisasi perlu melihat SDM sebagai human capital, dimana kompetensi SDM adalah asset eksisnya suatu organisasi. Dengan demikian, pengembangan SDM yang memperhatikan aspek kompetensi menghasilkan unsur organisasi yang berkualitas, konsisten, memiliki hubungan kerja efektif, tercapainya tujuan organisasi dan organisasi tetap eksis dalam lingkungan bisnis yang kompetetitif.

\section{Pengembangan SDM Organisasi Berbasis Bakat}

Terdapat beberapa definisi terkait manajemen talenta/bakat (talent management). Bakat merupakan ukuran nilai (Van Dijk, 2008) yang menggambarkan keterampilan, kemampuan, kekayaan, kelimpahan, bakat, sikap, dan disposisi (Kamus online www.merriam-webster.com). Joubert (2007) menyatakan bahwa bakat adalah kemampuan seseorang untuk menginspirasi dan membangkitkan emosi pada orang lain. Sementara Glen (2007) menyatakan bahwa bakat adalah produk dari kemampuan (kompetensi, pendidikan, pelatihan dan pengalaman), ditambah dengan motivasi (keterlibatan, kepuasan, tantangan dan kesejahteraan) dan peluang.

Van Dijk (2008) menyatakan bahwa unsur-unsur penting bakat meliputi: 1) potensi (kekuatan seseorang, pengaruh dan kemampuan untuk mencapai hasil); 2) minat yang sesungguhnya (gairah); 3) kecerdasan keterampilan (pembelajaran mental dan fisik dan kemampuan kinerja untuk bersaing, menaklukkan dan bertahan hidup); 4) kecerdasan kebajikan atau keunggulan moral dan integritas. Lebih lanjut, Joubert (2007) menambahkan ciri-ciri orang yang benarbenar berbakat, yakni memiliki hasrat untuk belajar, responsif terhadap model peran dan pengaruh inspirasional, haus prestasi, ambisi dan dorongan untuk supremasi, ketidaksesuaian dan perlawanan, swasembada dan preferensi untuk menyendiri, kerentanan fisik, dan atribut pribadi.

Kaitannya dengan PSDM berbasis bakat, Cunningham (2007) menyatakan bahwa untuk mengembangkan bakat diperlukan kontekstualisasi dengan mempertimbangkan dua pilihan strategis utama, yaitu menyelaraskan orang dengan peran dan menyelaraskan peran dengan orang. Menyelaraskan orang dengan peran menyiratkan preferensi terhadap perekrutan bakat, pembelajaran, dan pengembangan sambil menyelaraskan peran dengan orangorang yang berfokus pada pemanfaatan bakat melalui lingkungan kerja yang memungkinkan (Van Dijk, 2008). Lebih lanjut Van Dijk (2008) menyatakan bahwa organisasi yang memiliki kinerja tinggi dalam pengembangan bakat melakukan halhal seperti penciptaan/kaderisasi bakat, kalibrasi, menumbuhkan dan meningkatkan bakat, merawat dan membina bakat. Talent Align (2007) menambahkan bahwa pengembangan bakat merupakan pendekatan terintegrasi strategis untuk mengelola karier dari menarik, mempertahankan, dan mengembangkan hingga mentransisikan sumber daya manusia organisasi.

Dalam pengembangan SDM berbasis bakat, perlu dimulai dari identifikasi individu yang paling cocok dan kebutuhan pengembangan individual yang mengarah pada pengembangan kontribusi orang tersebut untuk pengembangan tim dan organisasi. McCauley dan Wakefield (2006) menyebutkan bahwa organisasi yang unggul dalam pengembangan bakat menunjukkan delapan praktik terbaik, yaitu mendefinisikan manajemen bakat secara luas, mengintegrasikan berbagai elemen manajemen bakat ke dalam sistem yang komprehensif, memfokuskan manajemen bakat pada bakat individu yang paling bernilai, membuat manajemen senior berkomitmen untuk pekerjaan manajemen bakat, membangun model kompetensi untuk 
menciptakan pemahaman bersama tentang keterampilan dan perilaku yang dibutuhkan dan dihargai oleh organisasi, memantau seluruh sistem bakat untuk mengidentifikasi potensi kesenjangan bakat, unggul dalam mengidentifikasi dan mengembangkan bakat serta kinerja manajemen dan retensi, dan mengevaluasi hasil dari sistem manajemen bakat.

Pengembangan bakat memegang nilai penting bahkan menjadi point kritis bagi perusahaan. Ini karena, dengan pengembangan bakat tersedianya karyawan berbakat dan unggul pada posisi-posisi yang dibutuhkan sehingga terjadi peningkatan performance dan mendongkrak performance perusahaan (Jumawan, 2015).

\section{Pengembangan SDM Organisasi Berbasis Ketahanan/Adversity Quotient}

Istilah Adversity Quotient dapat dimaknai sebagai kemampuan seseorang dalam menghadapi perjuangan dan mengatasi kesulitan ataupun masalah menjadi sebuah peluang demi pencapaian lebih besar (Labola, 2017). Stoltz (2000) menambahkan bahwa seseorang dengan $A Q$ tinggi akan mengolah kesulitan dengan kecerdasan yang dimiliki menjadi tantangan yang perlu diselesaikan. Dengan demikian bermanfaat bila kesulitan muncul dan dapat dipergunakan memprediksi keberhasilan/ kesuksesan.

Beberapa orang mencoba menghadapi berbagai persoalan, akan tetapi kembali ketika bertemu dengan terjalnya penderitaan (Supardi, 2013). Karena itu, kecerdasan ketahananlah jawaban seseorang mengatasi tantangan dan meraih puncak kesuksesan. Lebih lanjut, Supardi (2013) menyampaikan bahwa dengan kecerdasan ketahanan seseorang mampu meneduhkan intikad, membekuk onak, dan menawan persoalan untuk mengambil keuntungan. Dengan demikian, setiap usaha yang dilakukan meraih kesuksesan dan eksis dalam dunia kompetitif.

Di era yang kompetitif ini, dunia kerja memerlukan output yang kompeten, inovatif, tangguh, kompetitif dan mampu menjadi "bunglon" dalam berbagai situasi dalam suatu lembaga dan pekerjaannya. Semakin tinggi seseorang dalam karirnya, terdapat persoalan kompleks yang perlu dihadapi dan diselesaikan dengan solusi yang tepat. Karena itu, penerapan pengembangan SDM berbabasis $A Q$ perlu menjadi perhatian organisasi/lembaga yang mengedepankan ketangguhan karyawan.

Pengembangan SDM berbasis $A Q$ penting, karena dengan $A Q$ tinggi karyawan mampu melakukan beberapa hal seperti : 1) mengendalikan setiap persoalan yang mempunyai implikasinya positif dan bermanfaat untuk kinerja dan produktivitas; 2) bertanggung jawab, yakni memperluas kendali, pemberdayaan dan motivasi dalam mengambil tindakan (Supardi, 2013); 3) memiliki batasan terhadap persoalan, merespon masalah sebagai sesuatu yang spesifik dan terbatas (Sesanti, 2012); 4) tidak mudah putus asa, berprinsip bahwa kesulitan hanyalah sementara. Lebih lanjut Phoolka dan Kaur (2012) menyampaikan bahwa $A Q$ dapat digunakan untuk melakukan prediksi terhadap kemampuan dan ketekunan karyawan, digunakan dalam meningkatkan efektivitas tim, hubungan, keluarga, komunitas, budaya, masyarakat dan organisasi.

\section{Kesimpulan}

Berdasarkan uraian di atas, disimpulkan bahwa pengembangan SDM penting dilakukan sebagai program berkesinambungan demi tercapainya keberhasilan dan tujuan organisasi. Secara langsung pengembangan SDM organisasi berdampak pada pengembangan karir, bakat, dan ketangguhan karyawan dalam bekerja serta memberi paradigma baru bagi organisasi dalam mengembangkan sumber daya manusianya.

Aspek kompetensi, bakat dan ketahanan merupakan unsur fundamental penentu eksistensi organisasi dalam dunia bisnis yang kompetitif. Organisasi yang menerapkan kompetensi perlu memperhatikan tahapan-tahapan PSDM dan tingkatan manajemen. Dengan kompetensi, 
karyawan potensial, berkinerja efektif pada situasi pekerjaan yang bermuara pada daya saing dan konsistensi organisasi. PSDM berbasis bakat perlu dikontekstualisasikan dengan mempertimbangkan dua pilihan strategis orang dengan peran dan menyelaraskan peran dengan orang. Dengan demikian tercipta karyawan yang memiliki keterampilan, kemampuan, kekayaan, kelimpahan, bakat, sikap, dan disposisi serta mampu menjadi inspirator. Pengembangan SDM berbasis $A Q$ penting untuk mengendalikan setiap persoalan, bertanggung jawab, memiliki batasan terhadap persoalan, dan tidak mudah putus asa. Dengan aspek ketahanan karyawan dapat meneduhkan intikad, membekuk onak, dan menawan persoalan untuk mengambil keuntungan demi efektivitas organisasi untuk meraih kesuksesan dan eksis dalam dunia kompetitif.

\section{DAFTAR PUSTAKA}

Glen, C. 2007. Fostering Talent Opportunity: Getting Past First-Base. Strategic Direction, Volume 23 (10), 3-5.

Hutagalung, S. S. 2008. Pengembangan Sumber Daya Manusia Sektor Publik Berperspektif Human Power-Based. Jurnal Ilmiah Administrasi Publik dan Pembangunan, Vol.2, No.5, ISSN : 1410-8429.

I Prabawati, Meirinawati, T A Oktariyanda. 2018. Competency-Based Training Model For Human Resource Management And Development In Public Sector. IOP Conf. Series: Journal of Physics: Conf. Series 953. doi :10.1088/1742-6596/953/1/012157

Joubert, D. 2007. Talent Management: Deliberate practice for success. Randburg: Knowres Publishing.

Jumawan. 2015. Mengembangkan Sumber Daya Manusia (Hrm) Yang Strategis Untuk Menunjang Daya Saing Organisasi : Perspektif Competency \& Talent Management. Media Mahardhika Vol. 13 No. 3 Mei 2015

Kamidin, M. 2010. Pengaruh Kompetensi Terhadap Prestasi Kerja Pegawai
Sekretariat Daerah Kabupaten Bantaeng," Jurnal Economic Resources, Vol. 11, No. 30, pp. 79-91.

Kamus Merriam Webster. 1928. (online), https://www.merriam-webster.com/. pada tanggal 09 Mei 2019, pukul 19.00 WITA

Kemp, L. K dkk. 2004. Competency-Based Human Resource Management. https://trove.nla.gov.au/version/199709 50. 1st ed. xvi, $291 \mathrm{p}$.

Labola, Y. A. 2017. Perpaduan Aspek AQ dengan Aspek Kecerdasan Lainnya Dalam Dunia Pendidikan-Kajian Literatur. $\quad$ http://www.ejurnal.com/2017/08/perpaduanaspekaq-dengan-aspek.html

Long, C dan Ismail, W. 2011. An Analysis Of The Relationship Between HR Professionals' Competencies And Firms' Performance in Malaysia, International Journal of Human Resource Management, 22(5), pp. 1054-1068.

McCauley, C dan Wakefield, M. 2006. Talent Management in the 21st Century. The Journal for Quality and Participation, 29 (4).

Noe, R. A. 2008. Employee Training and Development. Fourth Edition. NewYork: McGraw-Hill.

Okoye, P.V.C and Ezejiofor, R. A. 2013. The Effect of Human Resources Development on Organizational Productivity. International Journal of Academic Research in Business and Social Sciences. Vol. 3, No. 10 ISSN: 2222-6990.

Pfeffer, J. 1998. The Human Equation: Building Profits by Putting People First. Cambridge, Mass: Harvard Business School Press.

Phoolka, S dan Kaur, N. 2012. Adversity quotient: a new paradigm to explore. International Journal of Contemporary Business Studies. 3(4):67-78.

Raven, J dan Stephenson, J. (Eds.). 2001. Competency in the Learning Society. New York: Peter Lang. 
Sesanti, D. M. 2012. Bab II: Kajian Teori. UIN Malang, http://etheses.uinmalang.ac.id/2251/6/08410095_Bab_2. pdf, diakses pada tanggal 13 Mei 2019. Shodhganga.

Chapter 1 , http://shodhganga.inflibnet.ac.in/bitstre am/10603/62613/10/11_chapter1.pdf, diakses pada tanggal 08 Mei 2019, pukul 19.00 WITA.

Simon, Herbert. 1997. Administrative Behavior: A Study of Decision-Making Processes in Administrative Organizations, 5th edition. New York, NY: Macmillian Company.

Spencer, N. L dan Spencer, M. S. 1993. Competence at Work : Models for Superrior Performance. John Wily \& Son,Inc. Mew York.

Susan, M. R. 2012. Women and Leadership in Higher Education Current Realities, Challenges, and Future Directions. Advances in Developing Human Resources, 14(2), 131-139.

Talent Align. 2007. Talent Management Processes in Organisations, http://www.

talentalign.com/talent_management_pr ocesses_in_organization.htm
Townsend K, Wilkinson A. 2010. Managing Under Pressure: HRM in Hospitals. Human Resource Management Journal. 20(4):332-338.

Tripathi, K dan Agrawal, M. 2014. Competency Based Management In Organizational Context: A Literature Review. Global Journal of Finance and Management. ISSN 0975-6477 Volume 6, Number 4: pp. 349-356.

U. S. Supardi. 2013. Pengaruh Adversity Qoutient Terhadap Prestasi Belajar Matematika. Jurnal Ilmiah Pendidikan MIPA (Jurnal Formatif) 3(1): 61-71 ISSN: 2088-351X

Van Dijk, H. G. 2008. The Talent Management Approach To Human Resource Management: Attracting And Retaining The Right People. Journal of Public Administration. Volume 43 number 3.1.

Wei, L dan Ming Lau, C. 2005. Market Orientation, HRM Importance And Competency: Determinants Of Strategic HRM In Chinese Firms. The International Journal of Human Resource Management 16(10):19011918. 